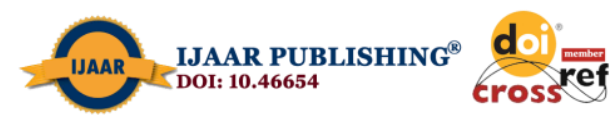

International Journal of Advanced Academic Research (Arts, Humanities and Education) | ISSN: 2488-9849

Vol. 6, Issue 11 (November, 2020) |www.ijaar.org

Journal DOI: 10.46654/ij.24889849

Article DOI: 10.46654/ij.24889849.a6113

\title{
SOCIO-DEMOGRAPHIC DETERMINANTS OF UNMET NEED FOR FAMILY PLANNING IN CRISIS-AFFECTED STATES OF NORTHERN NIGERIA
}

\author{
ADEGOKE, ADEMOLA ADEBAYO \\ Department of Demography and Social Statistics, \\ Obafemi Awolowo University, Ile-Ife, Osun State.
}

\begin{abstract}
This study ascertained the prevalence of unmet need for family planning in crisis-affected states of Northern (Yobe, Borno, Plateau, Kaduna, and Zamfara) Nigeria; ascertain the determining factors of unmet need for family planning in crisis-affected states of Northern Nigeria; and examine the relationship between demographic factors and unmet need for family planning in crisis-affected states of Northern Nigeria. The target population are women within the age range of 15 - 49 years selected from NDHS 2018 who have engaged in sexual activity and have experienced the burden of child bearing. The sample was weighted using the weights provided by the 2018 NDHS. The study sampled 8, 846 from the weighted total of 41, 821 women covered in the 2018 NDHS. Women who are not sexually active or have been sterilized and those who are pregnant were not included to the population of women sampled. The independent variable in this study is the unmet need for family planning in crisis affected states of Northern Nigeria; explanatory variable are sets of demographic variables (birth intervals, current age, number of living children, fertility desire, child mortality experience, marital status, couple fertility desire, type of marriage and age at first birth) while the mediating variables (pregnancy termination experience, attendance at ante-natal care, and timing of first antenatal visit).
\end{abstract}

Key Words: Unmet Need; Age at first birth; Age at marriage; Maternal age; Child mortality 


\section{INTRODUCTION}

Unmet need is among the measurements used to measure family planning successes (United States Agency for International Development, 2016). Unmet need for family planning explains the proportion of women of reproductive age that is married and desired to bring to an end or delay child bearing but are not currently using any form of birth control measures (World Health Organization, 2019). There was estimation that 105.2 million women do not have their need for family planning met in the developing world (Adedini, Odimegwu, Imasiku \& Ononokpono, 2015), these are women that would have wished to delay childbearing or put a stop to childbearing but are not using any means of contraceptives. It can also be described as the proportion of sexually active women that is married or in a relationship who need contraceptives for family planning but their demand is not been met (USAID, 2016). Thus, women with unmet need are those who are capable of bearing children and sexually active but are not using any method of contraceptive and report not wanting any more children or wanting to delay the next child (WHO, 2019). This implies that these women have the tendency to be pregnant anytime there is sexual activity but are not currently using any means of contraceptives and it is more noticeable in areas affected by insurgency or environmental disasters (Jain \& Muralidhar, 2011).

The internally displaced populations are always the most affected because of their condition. An agency of the United Nations (USAID, 2014) reports that access to family planning information and services especially in Internally Displaced People's homes can help reduce maternal deaths by $30 \%$ annually, save the lives of 1.4 million children under 5 each year, save about $\$ 6$ for every $\$$ linvested, and achieve about 17 sustainable development goals by 2020. Thus, there are new tools for frontline health workers across the world as reports put an estimated 68.5 million forcibly displaced people with about 25.4 million refugees (UNHCR, 2018).

\section{STUDY OBJECTIVES:}

(a) Assess the determining socio-demographic characteristics of unmet need in crisisaffected states of Northern Nigeria;

(b) Ascertain the relationship between socio-demographic characteristics and unmet need in crisis affected states of Northern Nigeria.

\section{Statement of Research Problem}

The high level of fear and insecurity has affected not only the socio-economic lives but also the sexual and reproductive lives of the internally displaced people (IDP) of Northern Nigeria. Its effect has even compounded high levels of procreation and the disinterest in the use of contraceptives in these states. Previous studies have focused on the fact that family planning has extensive advantages for everyone and for the society as a whole (Izugbara, Wekesah, Tilahun, Amo-Adje \& Dimbuene, 2018).

Studies have identified that unmet need are not met because most contributions to it have been shifted, people are not able to have access to the services rendered and the unwillingness of people to adopt family planning services (Machiyama \& Cleland, 2014). Research had been 
carried out on unmet need for family planning as it relates to access, information, and counseling (Sedgh \& Hussain, 2014). Valekar, Pande, Chawla \& Mane (2017) researched into the side effect of unmet need for family planning as among the determinant factors that have caused apathy. Scholars have identified demographic characteristics as a hindrance to unmet need for family planning that has not allowed women to take, make and implement family planning decisions (Mairiga, Kullima, Bako, Kolo \& 2010). Such decisions have resulted in varied reproductive health problems.

\section{Research Question}

What is the relationship between socio-demographic factors and unmet need for family planning in crisis-affected states of Northern Nigeria?

\section{Justification for Study}

The internally displaced people (IDPs) crowded in camps and displacement sites are living in congested shelters that are not secured or in difficult areas. Internally Displaced Monitoring Centre (2018) reported that 541,000 people were displaced in Nigeria, of which 200,000 of those displaced occurred in the Middle Belt region and the rest as a result of the Boko Haram insurgency in the North East. About 2.2 million people continued to be displaced from their residence due to Boko Haram, banditry and flood as of the end of 2018; this flood in particular affected 80 percent of the country in 2017 and brought about most of the 613,000 new displacements (IDMC, 2018). Communal conflicts are common social problems in Nigeria.

\subsection{Literature Review}

Literature review groups together, compares, and contrasts the varying opinions of different researchers on different areas of study. This chapter is a scholarly archive of related research findings on unmet need for family planning across boards.

\subsection{What is Unmet Need for Family Planning?}

Unmet need for family planning is appropriate only to married women and indicate those women who preferred to avoid pregnancy but are not willing to use any method of contraception (WHO, 2019). It is defined as the women of reproductive age (15-49) who are married or in a union and who have an unmet need for family planning to the total number of women of reproductive age (WHO, 2019). WHO (2019) gave two classifications of unmet need: the unmet need for child spacing and the unmet need for limiting. The unmet need for spacing is for women that wish to postpone their next birth by a certain number of years (at least two years), while the unmet need for limiting refers to those women who do not want any more children throughout life. Thus, women who are using contraceptives are referred to as those women with met need. If you add women with an unmet and met need you will get the total 'need' for family planning (Population Horizons, 2014). There are many situations or conditions that can cause unmet need for family planning and that not all women with unmet need for family planning are ready to use contraceptives (Chall, 1994) 


\section{Prevalence of Unmet Need for Family Planning across the World}

There are wide variations of unmet need across the globe. In Eastern Europe and Central Asia, statistics emanating have shown that there are lower levels of unmet need among married women of 15-24 which is proved by an increase in the demand for contraceptives (USAID, 2014). But in Kyrgyz republic there is still a rise of the prevalence of unmet need for family planning among married women with an increase of $8.6 \%$ and those who are using contraceptives had reduced from $45.5 \%$ in 1997 to $19.3 \%$ in 2012 (USAID, 2014).

In South and South East Asia there is a decline in unmet need $(25.5 \%)$ and a rise in the use of contraceptives which led to the fall of unmet need for family planning virtually in the two regions of Pakistan and Cambodia and ultimately led to increase level in the unmet need for family planning in Nepal from 33.8\% in 2001 to $39.3 \%$ in 2010 a decade after (USAID, 2014). Generally, Middle East and North Africa countries have experienced appreciable decline $(10.8 \%)$ in unmet need among married women of 15-24 but there is still fluctuation in country statistics. In Latin America and the Caribbean country statistics shows a downward trend for married women of age 15-24 that is supported by a boost in the demand for family planning services (USAID, 2014). Across the globe, Africa still has a very high rate of unmet need for family planning (29.3\%) with Ghana having the highest rate (45.7\%) as a dependent country. As at recent statistics, the North African countries have the lowest statistics in the continent which is in Egypt (8.8\%). However, there has been a fall among young married women in many countries (51 of 61 countries) with West and Central Africa having an exception where unmet need has increased in six countries within the region (USAID, 2014).

Male Partner Involvement: Male involvement had been linked to one of many factors that determine unmet need for family planning in crisis-prone states of Northern Nigeria (Nmadu et al., 2019). A research revealed that male involvements, promotion of spousal communications are the strong determinants of unmet need for family planning even in crisis-affected states (Nmadu, Joshua, Omole, Usman, Igboanusi, Gobir, 2019). The male involvement is expected to reduce the diffident of going to family planning clinics and the poor level of understanding among the male partner (Dral, Tolani, Smet, \& VanLuisn, 2018). This is in corroboration to a study in Uganda (Waf \& Ssekamatte-Ssebullba, 2000) on the duties of couple at agreeing in unmet need that shows that partner opposition causes a statistically significant increase in unmet need. If focus could be shifted to men's attitudes towards contraception and improve on communication within couples, it will reduce unintended pregnancy. In Zimbabwe it was reported that in spite of men's account of taking the final decision on contraceptive use, women are the user of contraceptives (Sensoy et al., 2017). In a refugee Camp, Imo State of Nigeria for instance, the male involvement is a strong determining factor that need to be considered. Here is an excerpt experience of a male in the camp:

"That his girl friend is in the habit of using pills to prevent her from been pregnant. The boy said that he had advised her to stop using all these contraceptives since they are meant for people who are married and have children and that he preferred they use condom instead of using the contraceptive pills" (Okanlawon, Reeves \& Agbaje, 2010). 
Birth Intervals: Almost every woman that has ever given birth has a most relent birth which stands at some point removed from it, in an "open interval" (Ross \& Bietsch, 2019). This open interval means that some women will go on to another pregnancy and birth while some will not and will remain permanently in the open interval.

Age Influences: A study (Solanke, 2017) on the pioneer of unmet need for family planning amongst fully grown women was studied with the use of a combined Nigerian Demographic Health Survey data of 2008 and 2013; the study concluded that issues of marriage, couple's fertility desire, marital age and other demographic characteristics exert more influence on unmet need than socio-economic reasons and that older people do not get the care and support they need and have risen more than 1.4 million (AgeUK). Bhaltathiry \& Ethirajan, (2014) have adjudged that in Imo State of Nigeria the use of family planning method was low and factors of age, religion, family size were adjudged to be the cause.

\section{Marital Status}

A study on the impact of parity and marital status on contraceptives was carried out on 73 low and middle-income countries and it was discovered that in most of the countries, the modern contraceptive prevalence was low among married female adolescents without children (Numes Coll, Ewerling, Hellwig \& Bamos, 2019). His findings further suggested that social norms regarding marriage and fertility play a relevant role in contraceptive use. Some other researchers have pointed differently (Numes Coll et al., 2019). The type of marriage a woman is involved is another factor in consideration. Based on a comparative DHS Comparative Research Report 44 (Wang, Staveteig, Winter \& Allen, 2017) that women in Polygyny marriages are more likely to be older, have more children, be less educated, live in an impoverished household and reside in a rural area and that these women have lower tendency to use a contraceptive method when compared to women in monogamous marriages. Findings from a study in Saudi Arabia to know the core reasons why women do not use contraceptives and to know the associated reasons concluded that most of the women in the Asia region had unmet need (Khalif, Alzahrami \&Siddiqui, 2018).

\section{Child Mortality}

Studies have examined the influence of child mortality on unmet need for family planning. A finding (Adedini, Odimegwu, Imasiku \& Ononokpond, 2015) with the use of 2008 National Demographic Health Survey data concluded that there are increased risks of under-five death for children whose mothers had unmet need for spacing and for limiting when compared to those women that do not have unmet need issue. Family planning programme should be fully integrated to the policies of nations thereby accelerating the attainment of the sustainable development goals (UNFPA, 2008).

\section{Influences of Social Media on Unmet Need for Family Planning}

The role played by the media cannot be over emphasized. Thus, radio and television messages are germane to the creation and changing of values, ideas, and attitudes of people in public health 
(Adekunle, Olaseha \& Adeniyi, 2004). The role of radio and television has been expressed as two important means of disseminating information from the Bangladesh experience of information on the use of contraceptives (Hasan \& Baten, 2005). Adequate social media could improve access and positive response to the use of contraceptives in the spacing of children. A research carried out on displaced women of Somali descent living in Finland showed that majority of these women did not initially use contraceptives (Degni, Koivusilta, \& Ojanlatva, 2006) but later they began to use it because of the easy availability of the contraceptives (Koivusita \& Ojanlatva, 2006).

\section{Theoretical Focus (Social Action Theory)}

The appropriate theoretical framework that guides this study is the Social Action Theory. The founder of this theory was Max Weber. This theory examines smaller groups in the society. It is concerned with the personal state of person. It views the society as a creation of human activity. Generally, the family planning program is aimed at changing or altering an individual's fertility behavior. The need for the existence of a family planning programme presumes that an individual's fertility expectations and behaviour is still not consistent with the objectives of reducing family size. But when family planning use continues to be relatively low even when resources and information are available, it is pertinent to know what has kept families from using modern perspectives. A social action is an action done by an individual to which an individual attached an importance. It cannot be a social activity because it does not involve thinking. Thus, the unmet need for family planning can be described as a social action because of its motive and intent. It is the motive and intention that this study is interested at.

\section{Study Hypotheses}

1. Age at first birth does not have significant effect on unmet need for family planning in crisisaffected states of Northern Nigeria.

2. Age at marriage does not have significant effect on unmet need for family planning in crisisaffected states of Northern Nigeria

3. Maternal age does not have significant effect on unmet need for family planning in crisisaffected states of Northern Nigeria.

4. Child mortality experience does not have significant effect on unmet need for family planning in crisis-affected states of Northern Nigeria.

\section{METHODOLOGY}

\section{Data Source:}

This study analyzed data extracted from the Women data of 2018 Nigeria Demographic and Health Survey (NDHS), which is the seventh round of the Demographic and Health Survey (DHS) programme to be implemented in Nigeria. 


\section{Target Population:}

The target population in the study is women of reproductive age 15 to 49 years. Women are targeted in the study for two reasons. One, most women in the country who engage in sexual activity and bears the burden of childbearing do so under circumstances that are beyond their control. Nigeria being a heavily male-dominated society has a lot of socio-cultural practices and norms that expose women to poor sexual and reproductive health such as non-use of modern contraception, gender-based violence, unintended pregnancies, unsafe abortion, and infections with sexually transmitted diseases including HIV/AIDS.

\section{Sample Size:}

A weighted total of 41,821 women were covered in the 2018 NDHS. These included a lot of women that are not relevant to the study. Hence, some of the women are excluded from this study. To exclude some women from the analysis, the study first excluded all women from the states that were not selected for the study, which indicates that only women from Zamfara, Yobe, Borno, Kaduna, Plateau, and Benue states are analysed in the study. Also, women who are not sexually active or have been sterilized or declared infecund or currently pregnant are excluded from this study. These women are excluded because they do not need any contraceptive methods and have no exposure to pregnancy. The study, therefore, was based on a sample size of 8,846 women. The sample was weighted using the weights provided by the 2018 NDHS. The importance of weighting NDHS data is the need to eliminate oversampling and bias between rural and urban areas of the selected states.

Table 1: Variable Identification and Description

\begin{tabular}{|l|l|l|l|}
\hline S/No. & Name of Variable & Description & Code \\
\hline Outcome Variable & $\begin{array}{l}\text { Unmet need for family } \\
\text { planning }\end{array}$ & $\begin{array}{l}\text { Non-use of contraception } \\
\text { among women who want } \\
\text { to limit childbearing or } \\
\text { delay next pregnancy }\end{array}$ & $\begin{array}{l}1 . \text { Unmet need } \\
0 . \quad \text { No unmet need }\end{array}$ \\
\hline 1. & &
\end{tabular}

Demographic variables in-use: birth interval, maternal age, no. of living children, planning status of last birth, age at first marriage, child mortality experience, current marital status, fertility desire.

\section{Data Management}

The STATA version 14 (StatCorp, 2015) was used for data processing, handling, and analyses in the study. This requires identification of the research variables in the datasets, and the generation or recoding of some variables to make them compatible with the study objectives.

\section{Method of Data Analysis}

The data extracted for the study were analyzed. The associations between variables were accepted as significant if the p-value was less than 0.05 with confirmation of the $95 \%$ confidence 
interval. The analyses were carried out at the univariate and bivariate level of analysis. The univariate measures the demographic characteristics of the respondents. The bivariate analyses are carried out in two stages. In the first stage, the explanatory variables are cross-tabulated with unmet need for family planning in the selected states, while in the second stage; the unadjusted binary logistic regression was carried out to assess the significance of the relationship between the explanatory variables and unmet need for family planning.

\section{Ethical considerations}

The data analyzed in the study were accessed through formal requests and permission of the owners of the data. The analyses did not identify any respondent or community or household. The results of the analyses cannot be associated with any individual, family or community, which makes the findings not to be harmful to any person or community. Besides, the 2018 NDHS was approved for execution in Nigeria by the Federal Ministry of Health.

\section{Table 2: Demographic Characteristics}

\begin{tabular}{|c|c|c|c|}
\hline \multicolumn{2}{|r|}{ Name of Variable } & \multicolumn{2}{|c|}{ Description $\quad$ Code } \\
\hline 1. & Number of living children & $\begin{array}{lr}\text { Respondent living } \\
\text { children from the } \\
\text { children ever born }\end{array}$ & $\begin{array}{l}\text { 1. } \begin{array}{l}\text { Four or less } \\
\text { children }\end{array} \\
\text { 2. Five or more } \\
\text { children }\end{array}$ \\
\hline 2. & Maternal age & $\begin{array}{l}\text { Respondent current age } \\
\text { group }\end{array}$ & $\begin{array}{l}\text { 1. 15-24 years } \\
\text { 2. 25-34 years } \\
\text { 3. } 35 \text { years and } \\
\text { above }\end{array}$ \\
\hline 3. & Age at first marriage & $\begin{array}{l}\text { The age at which } \\
\text { respondent first entered } \\
\text { into a marital union }\end{array}$ & $\begin{array}{l}\text { 1. } 17 \text { years or less } \\
\text { 2. } 18-24 \text { years } \\
\text { 3. } 25 \text { years and } \\
\text { above }\end{array}$ \\
\hline 4. & Age at first birth & $\begin{array}{lr}\text { The age respondent } \\
\text { commences } \\
\text { childbearing }\end{array}$ & $\begin{array}{l}\text { 1. } 14 \text { years or less } \\
\text { 2. 15-19 years } \\
\text { 3. 20-24 years } \\
4.25 \text { years and } \\
\text { above }\end{array}$ \\
\hline 5. & Current marital status & $\begin{array}{l}\text { Whether respondent is } \\
\text { currently married or not } \\
\text { (never, separated, } \\
\text { widowed or divorce) }\end{array}$ & $\begin{array}{l}\text { 1. Not currently } \\
\text { married } \\
\text { 2. Currently married }\end{array}$ \\
\hline 6. & Type of marriage & $\begin{array}{l}\text { Whether respondent } \\
\text { husband is married to } \\
\text { respondent alone or } \\
\text { simultaneously married } \\
\text { to at least one other } \\
\text { woman }\end{array}$ & $\begin{array}{l}\text { 1. Monogamy } \\
\text { 2. Polygyny }\end{array}$ \\
\hline
\end{tabular}




\begin{tabular}{|c|c|c|c|}
\hline 7. & Wanted the last child & $\begin{array}{l}\text { The extent to which } \\
\text { respondent planned the } \\
\text { pregnancy or birth of the } \\
\text { last child }\end{array}$ & $\begin{array}{l}\text { 1. Wanted } \\
\text { 2. Mistimed } \\
\text { 3. Unwanted }\end{array}$ \\
\hline 8. & Birth interval & $\begin{array}{l}\text { The difference in months } \\
\text { between two successive } \\
\text { months }\end{array}$ & $\begin{array}{l}\text { 1. Less than } 24 \\
\text { months } \\
\text { 2. } 24 \text { to } 35 \text { months } \\
\text { 3. } 36 \text { months or } \\
\text { more }\end{array}$ \\
\hline 9. & Couple fertility desire & $\begin{array}{l}\text { The number of children } \\
\text { husband and wife desire } \\
\text { to have individually }\end{array}$ & $\begin{array}{l}\text { 1. Both want same } \\
\text { 2. Husband want } \\
\text { more } \\
\text { 3. Husband want } \\
\text { fewer } \\
\text { 4. Don't know }\end{array}$ \\
\hline 10. & Child mortality experience & $\begin{array}{l}\text { Respondent experience } \\
\text { of death of either a male } \\
\text { or female child among } \\
\text { children ever born }\end{array}$ & \begin{tabular}{|cc}
1. & Never \\
experienced & \\
2. & Ever \\
experienced & \\
\end{tabular} \\
\hline
\end{tabular}

Table 3: Univariate Level of Measurement of Demographic Characteristics of Respondents

\begin{tabular}{|l|l|l|}
\hline Characteristic & Number of Women & Percentage \\
\hline Birth Interval & 4,553 & 51.5 \\
\hline Less than 2 years & 2,139 & 24.2 \\
\hline 2 to 3 years & 2,150 & 24.3 \\
\hline 3 years or more & \multicolumn{2}{l|}{} \\
\hline Maternal age & 3,588 & 40.6 \\
\hline 15-24 years & 2,768 & 31.3 \\
\hline 25-34 years & 2,490 & 28.1 \\
\hline 35 years and above & \multicolumn{2}{|l|}{} \\
\hline Number of Living Children & 6,614 & 74.8 \\
\hline 4 or less & 2,232 & 25.2 \\
\hline 5 or more & \multicolumn{2}{|l|}{} \\
\hline Planning status of last birth & 8,463 & 95.7 \\
\hline Wanted & 288 & 3.2 \\
\hline Mistimed & 96 & 1.1 \\
\hline Unwanted & 6,369 & 72.0 \\
\hline Age at first marriage & 2,063 & 23.3 \\
\hline 17 years or less & \multicolumn{2}{|l|}{} \\
\hline 18-24 years &
\end{tabular}


Journal DOI: 10.46654/ij.24889849

Vol. 6, Issue 11 (November, 2020) | www.ijaar.org

Article DOI: 10.46654/ij.24889849.a6113

\begin{tabular}{|c|c|c|}
\hline 25 years or older & 412 & 4.7 \\
\hline \multicolumn{3}{|c|}{ Child mortality experience } \\
\hline Ever experienced & 2,164 & 24.5 \\
\hline Never experienced & 6,682 & 75.5 \\
\hline \multicolumn{3}{|l|}{ Current marital status } \\
\hline Not currently married & 2,360 & 26.7 \\
\hline Currently married & 6,486 & 73.3 \\
\hline \multicolumn{3}{|l|}{ Couple fertility desire } \\
\hline Both want more & 2,112 & 23,9 \\
\hline Husband want more & 3,253 & 36.8 \\
\hline Husband want fewer & 2,890 & 32.7 \\
\hline Don’t Know & 591 & 6.7 \\
\hline \multicolumn{3}{|l|}{ Type of marriage } \\
\hline Monogamy & 4,051 & 45.8 \\
\hline Polygyny & 4,795 & 54.2 \\
\hline \multicolumn{3}{|l|}{ Age at first birth } \\
\hline 14 years or less & 3,131 & 35.4 \\
\hline $15-19$ years or less & 3,607 & 40.8 \\
\hline $20-24$ years & 1,590 & 18.0 \\
\hline 25 years or more & 518 & 5.8 \\
\hline \begin{tabular}{|l|} 
Total \\
\end{tabular} & & \\
\hline
\end{tabular}

Source: Analysis based on 2018 Nigeria Demographic and Health Survey

\section{RESULTS \& DISCUSSION:}

Almost all the respondents (95.7\%) wanted their most recent birth compared to the $3.3 \%$ of respondents who mistimed their most recent birth and the $1.1 \%$ who did not want their most recent birth. The majority of the respondents $(72.0 \%)$ married at age 17 years or younger ages but $23.3 \%$ of the respondents got married between age 18 and 24 years compared to the $4.7 \%$ that got married at age of 25 years or older ages. The majority of the respondents (75.5\%) had never experienced child death compared to $24.5 \%$ who had experienced child death. The majority of the respondents (73.3\%) were currently married compared to $26.7 \%$ who were not currently married. Respondents' husbands who wanted more children than the respondents had a higher proportion $(36.8 \%)$ while respondents whose husbands wanted fewer children were $32.7 \%$ of the total respondents. Less than one-quarter of the respondents $(23.9 \%)$ had the same fertility desire with their husbands but $6.7 \%$ of the respondents do not know their fertility desire. More than half of the respondents (54.2\%) were in polygynous unions compared to the $45.8 \%$ who were in monogamous unions. The most common age interval for first birth was age 15-19 years $(40.8 \%)$ but more than one-third of the respondents (35.4\%) had their first birth at the age 
of 14 years or less. Age 25 years or older was the least age for first birth among the respondents $(5.9 \%)$.

Figure 1 presents the prevalence of unmet need for family planning among the respondents. As could be observed from the figure below majority of the respondents (87.0\%) did not have unmet need for family planning compared to the $13.0 \%$ who had unmet need for family planning.

\title{
Prevalence of Unmet Need for Family Planning
}

\author{
- No unmet Need $\quad$ Unmet Need
}

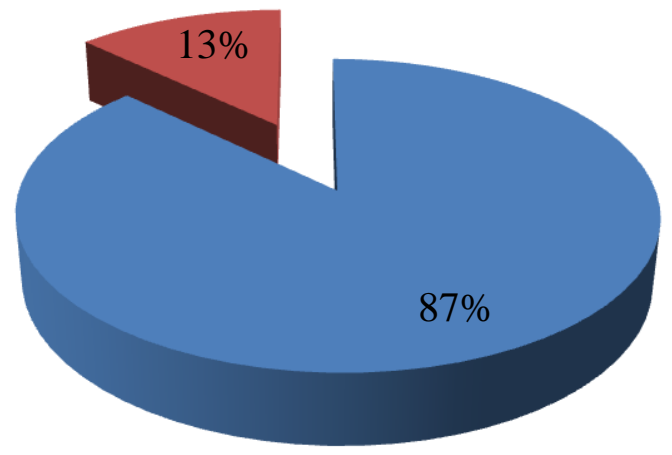

Figure 1: Prevalence of Unmet Need for Family Planning

Figure 2 represents the prevalence of unmet need for family planning in the selected states. The results show that unmet need for family planning was highest in Yobe state (15.2\%) and lowest in Kaduna state $(10.9 \%)$. 

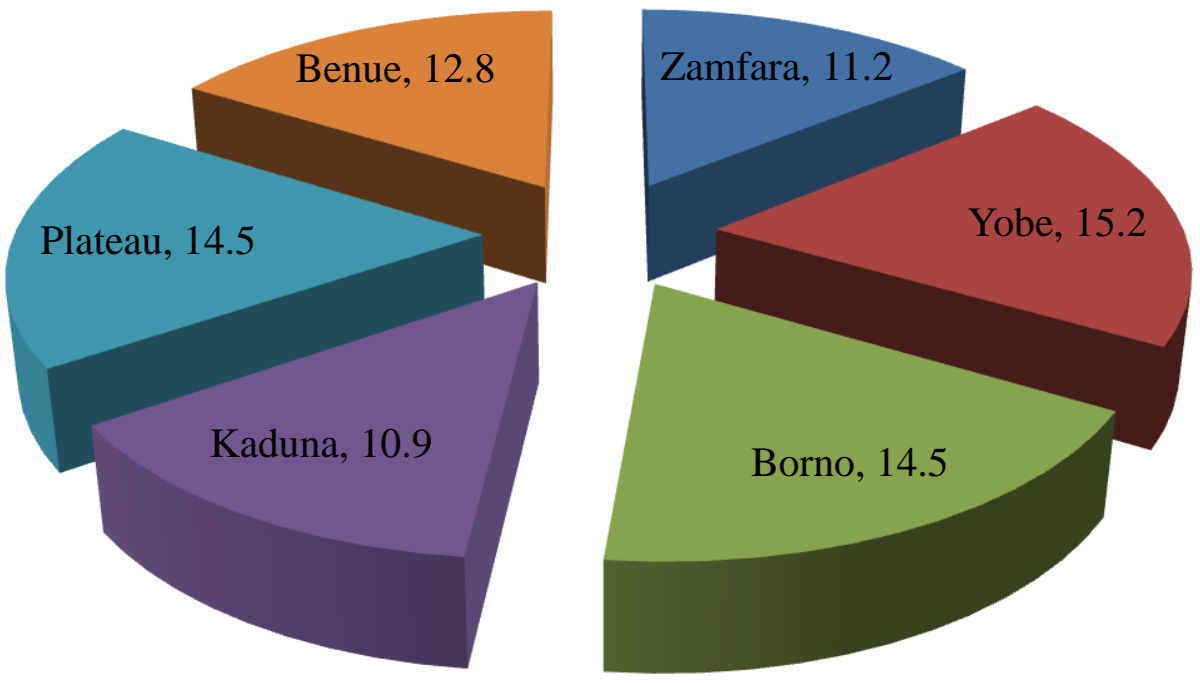

Figure 2: Prevalence of Unmet Need for Family Planning in selected states

Bivariate relationship of Demographic Characteristics of Respondents

Table 4.2.2 Demographic Characteristics and Unmet Need for Family Planning

\begin{tabular}{|c|c|c|c|c|c|}
\hline \multirow[t]{2}{*}{ Characteristic } & \multicolumn{2}{|c|}{$\begin{array}{l}\text { Unmet Need for Family } \\
\text { Planning }\end{array}$} & \multirow[t]{2}{*}{ UOR } & \multirow[t]{2}{*}{ p-value } & \multirow[t]{2}{*}{$95 \% \mathrm{CI}$} \\
\hline & $\begin{array}{l}\text { No unmet } \\
\text { Need (\%) }\end{array}$ & $\begin{array}{l}\text { Unmet } \\
\text { Need }(\%)\end{array}$ & & & \\
\hline \multicolumn{6}{|l|}{ Birth Interval } \\
\hline Less than 2 Years & $4,142(91)$ & $410(9.0)$ & 1.972 & 0.000 & $1.685-2.309$ \\
\hline $2-3$ Years & $1,792(83.8)$ & $347(16.2)$ & 2.061 & 0.000 & $1.763-2.409$ \\
\hline More than 3 Years & $1,772(82.5)$ & $377(17.6)$ & 1.000 & - & - \\
\hline \multicolumn{6}{|l|}{ Maternal Age } \\
\hline $15-24$ & $3,365(93.8)$ & $223(6.2)$ & 2.466 & 0.000 & $2.074-2.933$ \\
\hline $25-34$ & $2,350(85)$ & $418(15.1)$ & 3.285 & 0.000 & $2.772-3.892$ \\
\hline $35+$ & $1,995(80.1)$ & $495(19.9)$ & - & - & - \\
\hline \multicolumn{6}{|c|}{ No of Living Children } \\
\hline 4 or Less & $5,988(90.5)$ & $626(9.5)$ & 2.860 & 0.000 & $2.504-3.267$ \\
\hline 5 or More & $1,722(77.2)$ & $510(22.8)$ & 1.000 & - & - \\
\hline \multicolumn{6}{|c|}{ Planning Status of Last Birth } \\
\hline Wanted & $7,532(89.0)$ & $931(11.0)$ & - & - & - \\
\hline
\end{tabular}


Journal DOI: 10.46654/ij.24889849 Vol. 6, Issue 11 (November, 2020) | www.ijaar.org

Article DOI: 10.46654/ij.24889849.a6113

\begin{tabular}{|c|c|c|c|c|c|}
\hline Mistimed & $134(46.7)$ & $153(53.3)$ & 8.601 & 0.000 & $6.661-11.105$ \\
\hline Unwanted & $44(45.9)$ & $52(54.1)$ & 9.740 & 0.000 & $6.320-15.011$ \\
\hline \multicolumn{6}{|l|}{ Age at First Marriage } \\
\hline 17 or Less & $5,600(87.9)$ & $769(12.0)$ & 1.000 & - & - \\
\hline $18-24$ Years & $1,757(85.1)$ & $307(14.9)$ & 1.285 & 0.000 & $1.110-1.486$ \\
\hline 25 or Older & $352(85.5)$ & $60(14.6)$ & 1.104 & 0.523 & $0.815-1.500$ \\
\hline \multicolumn{6}{|c|}{ Child Mortality Experience } \\
\hline Ever Experienced & $1,741(80.4)$ & $424(19.6)$ & - & - & - \\
\hline Never Experienced & $5,969(89.3)$ & $712(10.7)$ & 0.257 & 0.000 & $0.450-0.592$ \\
\hline \multicolumn{6}{|l|}{ Current Marital Status } \\
\hline Not Currently Married & $2,290(97.1)$ & $70(30$ & 1.000 & - & -- \\
\hline Currently Married & $5,420(83.6)$ & $1,066(16.4)$ & 6.463 & 0.000 & $5.002-8.350$ \\
\hline \multicolumn{6}{|l|}{ Fertility Desire } \\
\hline Both Want Same & $1,794(85)$ & $318(15.1)$ & 1.000 & - & - \\
\hline Husband Want More & $2,741(84.3)$ & $512(15.8)$ & 1.203 & 0.021 & $1.028-1.408$ \\
\hline Husband Fewer & 2,707 (93.7) & $183(6.3)$ & 0.400 & 0.000 & $0.327-0.489$ \\
\hline Don't Know & $469(79.2)$ & $123(20.8)$ & 1.654 & 0.000 & $1.311-2.087$ \\
\hline \multicolumn{6}{|l|}{ Type of Marriage } \\
\hline Monogamy & $3,414(84.3)$ & $637(15.7)$ & - & - & - \\
\hline Polygyny & $4,296(900$ & $499(10.4)$ & 0.640 & 0.000 & $0.564-0.730$ \\
\hline \multicolumn{6}{|l|}{ Age at First birth } \\
\hline 14 or Less & $2,923(93.4)$ & $208(6.7)$ & 1.000 & - & - \\
\hline $15-19$ Years & $3,038(84.2)$ & $569(15.8)$ & 2.734 & 0.000 & $2.298-3.523$ \\
\hline $20-24$ years & $1,309(82.3)$ & $281(17.7)$ & 2.993 & 0.000 & $2.453-3.653$ \\
\hline 25 Years or More & $441(85.1)$ & 77 (14.9) & 2.375 & 0.000 & $1.764-3.199$ \\
\hline
\end{tabular}

Table: 4

\section{Results \& Discussion:}

The above (table 4) shows the socio-demographic characteristics of respondents and unmet need for family planning; those women with birth interval of two to three years had higher prevalence of unmet need for family planning (17.6\%) compared to those whose birth intervals are less than two years $(9.0 \%)$. However, both still show a significant relationship with unmet need for family planning as confirmed by the unadjusted logistic regression and the $\mathrm{p}$ value (UOR $=1.972$, $\mathrm{p}<0.05$; CI: $1.685-2.309)$ and (UOR=2.061, p<0.05; CI: $1.763-2.409)$.

Maternal age of respondents showed that the prevalence of unmet need for family planning was higher among women who have become mothers at the age of 25-34 years (15.1\%) as compared to women who gave birth at ages $15-24$ years $(6.2 \%)$. But, both ages still shows a significant relationship with unmet need for family planning $(\mathrm{UOR}=3.285, \mathrm{p}<0.05$; CI: $2.772-3.892)$ and (UOR=2.466, p<0.05; CI: $2.024-2.933)$.

The percentage of women who have had living children whose age are above five years old (22.8\%) have more prevalence for unmet need for family planning compared to those with ages 
four years or less $(9.5 \%)$. Thus women whose children are still below the age of four years old have significant relationship with unmet need for family planning (UOR=2.860, $\mathrm{p}<0.05$; CI : $2.504-3.267)$.

Women whose birth plan are unwanted (54.1\%) and mistimed (53.3\%) have significant relationship with unmet need for family planning. But this relationship was further confirmed by the unadjusted logistic regression that further showed that those whose pregnancy are unwanted and mistimed had lower odds of unmet need for family planning.

Age at first marriage for unmet need for family planning revealed that those who married at ages 18-24 years had significant relationship with unmet need for family planning ( $\mathrm{UOR}=1.285$, $\mathrm{p}<0.05 ; \mathrm{CI}: 1.10-1.1 .486$ )

Mothers who have ever experienced child mortality have high prevalence of unmet need for family planning $(19.6 \%)$ than those who never experienced child mortality. But there is a significant relationship of mothers who have never experienced child mortality with unmet need for family planning (UOR $=0.257, \mathrm{p}<0.005$; CI: $0.450-0.592)$.

Women who are currently married had higher prevalence of unmet need for family planning (16.4\%) compared to those women that are not currently married (3\%) which put a significant relationship of those currently married with unmet need for family planning (UOR $=0.257$, $\mathrm{p}<0.05$; CI : $0.450-0.592$ ).

Those who do not know their fertility desire (20.8\%) have higher prevalence of unmet need for family planning than those women whose husband want more children (15.8\%) and spouse whose fertility desire for children are equal. They all show a significant relationship with unmet need for family planning.

Women whose type of marriage is Polygyny have significant relationship with unmet need for family planning $(\mathrm{UOR}=0.642, \mathrm{p}<0.005 ; \mathrm{CI}: 0.564-0.730)$.

Women who had their first birth at age $20-24$ years $(17.7 \%)$ have higher prevalence of unmet need than all other age at first birth. Though all other ages with the exception of those whose age at first birth is 14years or less have significant relationship with unmet need for family planning $(\mathrm{UOR}=2.734, \mathrm{p}<0.005$; CI: 2.298 - 3.523); (UOR=2.993, p<0.005; CI: $2.453-3.653)$ and $(\mathrm{UOR}=2.375$, p<0.005; CI: $1.764-3.199)$.

\section{Itivariate Level of Demographic Characteristics on Unmet Need for Family Planning in Crisis-Affected States of Northern Nigeria}

The selected explanatory variables found to be statistically significant and have relationship with the dependent variables in the Bivariate analysis were further tested in the multivariate analysis using binary logistic regression model. The effects of the independent variables on the dependent variables were further analyzed for selected variables for which statistically significant relationship were established in the Bivariate analysis. The response variables were dichotomized to take a value of 1 for those with unmet need and 0 for those whose need was met. 
Table: 5

\begin{tabular}{|l|l|l|l|}
\hline Variable & Odd ratio & p- value & 95\% CI \\
\hline BIRTH INTERVAL & & & \\
\hline Less than 2- years & .8616349 & 0.147 & $.7041322-1.054368$ \\
\hline $2-3$ years & .8961924 & 0.301 & $.7274848-1.104024$ \\
\hline MATERNAL AGE & & & \\
\hline $15-24$ & 1.554564 & 0.002 & $1.171526-2.062839$ \\
\hline $25-34$ & 2.094809 & 0.000 & $1.487736-2.9496$ \\
\hline NO OF LIVING CHILDREN & 1.586863 & 0.000 & $1.268435-1.98523$ \\
\hline PLANNING STATUS OF BIRTH & 5.354457 & 0.000 & $2.871233-9.98533$ \\
\hline AGE AT MARRIAGE & & & \\
\hline $18-24$ & .7201399 & 0.008 & $.5661958-.9159404$ \\
\hline 25 or older & .6233249 & 0.025 & $.4122052-.942574$ \\
\hline CURRENT MARITAL STATUS & .5 .433837 & 0.000 & $3.504266-8.425896$ \\
\hline FERTILITY DESIRE & & & \\
\hline Husband want more & 1.098179 & 0.454 & $.8584884-1.404792$ \\
\hline Husband fewer & 1.384128 & 0.044 & $1.009475-1.897829$ \\
\hline Don't know & 1.464786 & 0.024 & $1.052411-2.038746$ \\
\hline TYPE OF MARRIAGE & .9472777 & 0.571 & $.7847786-1.143424$ \\
\hline AGE AT FIRST BIRTH & & & \\
\hline $15-19$ years & .9838301 & .0 .880 & $.7957024-1.216437$ \\
\hline $20-24$ years & 1.365581 & 0.045 & $1.007474-1.850978$ \\
\hline 25 years + & 1.07958 & 0.734 & $.6931788-1.681174$ \\
\hline
\end{tabular}

\section{Results \& Discussion}

Consistently, the variables tested (table 5) on demographic influence on unmet need for family planning in crisis-affected states revealed that maternal age for ages 15-24 (odd ratio=1.554564, $\mathrm{p}<0.05$ ) and 25-34 (odd ratio $=2.094809, \mathrm{p}<0.05$ ) have significant influence in these states and is a major predictor; likewise for the no. of living children (odd ratio $=1.586863, \mathrm{p}<0.05$ ); planning status of last birth (odd ratio $=5.354457, \mathrm{p}<0.05$ ); age at marriage for ages $18-24$ and age 25 years and above (odd ratio $=.7201399, \mathrm{p}<0.05$; odd ratio $=.6233249, \mathrm{p}<0.05$ ) respectively; current 
marital status (odd ratio=5.433837, $\mathrm{p}<0.05$ ); fertility desire for the husband that want fewer children and for those whose response were unknown (odd ratio $=1.384128, \mathrm{p}<0.05 ; 1.464786$, $\mathrm{p}<0.05$ ) respectively; and age at first birth for ages 20-24 years (odd ratio=1.365581, $\mathrm{p}<0.05$ ). Thus, birth intervals (odd ratio $=.4616349, \mathrm{p}>0.05$ ) and type of marriage (odd ratio $=.7472777$, $\mathrm{p}>0.05$ ) are not predictors or influence to unmet need for family planning in crisis-affected states of Northern Nigeria.

\section{CONCLUSION:}

From this study, it was discovered that the actual proportion of people with unmet need represented $13 \%$ of the population considered while $87 \%$ did not actually have an unmet need. Furthermore, among the states in focus, Yobe state has the highest percentage of unmet need $(15.2 \%)$ and Kaduna State has the least (10.9\%).

Thus, age at first birth, age at marriage (18-28), Maternal age, and child mortality experience do determine unmet need for family planning in crisis-affected states of Northern Nigeria since $\mathrm{p}<0.05$ as explained above in the results and discussion.

\section{RECOMMENDATIONS}

1. This study recommends that the stakeholders in these crisis affected states of Northern Nigeria should improve on the socio-economic factors and development of the people.

2. Reproductive health challenges such as maternal and motherhood should be given strong consideration so as to reduce the unmet need for family planning thereby bringing about the quick attainment of national policy programmes and many of the objectives of the sustainable development goals.

3. The government of the states concerned should build more family planning clinics and also make sure that there is integration of family planning clinics in hospitals. 


\section{REFERENCES}

Adedini, S., A., Odimegwu, C., Imasiku, E., N., \& Omonokpond (2015). Unmet need for family planning: Implications for under-five mortality in Nigeria. J.Health Population Nutr., 33(1): $187-206$

Adekunle,L., Olaseha,I.O.\& Adeniyi, J. D. (2004). Potential Impact of the Mass media on Family in an Urban Community in South Western Nigeria. Tropical journal of Obstetrics and Gynaecology, 21(20)

Degni, D. F., Koivusilta L \& Ojanlatva A.(2006).Attitudes towards and perceptions about contraceptive use among married refugee women of Somali descent living in Finland. The European Journal of Contraception \& Reproductive Health Care, 11(30), 190 - 6. https://doi.org/10.1080/13625/806005576

Dral A., Tolani, M., Smet, E., \& Van Luijn, A. (2018). Factors Influencing Male Involvement in Family Planning in Ntchisi District, Malawi - A qualitative study, 22 (4).

Federal Ministry of Health (2014). Nigeria Family planning blueprint (scale-up plan) - October, 2014

Hasan,S. \& Baten, A.(2005). Role of mass media in promotion of family in Bangladesh. 5(7), 1158-1162. URL:https://scalert.net/abstract/>doi=jas.2005.1158.1162

Izugbara, C., Wekesah,F., Tilahun, T., Amo-Adje, J. \& Dimbuene, Z.T.(2018). Family planning in East Africa: trends \& dynamics. African Population and Health Research Centre,

Jain, R., \& Muralidhar, S. (2011). Contraceptive Methods: Needs, Options and Utilization. Journal of Obstetrics and Gynaecology of India, 61(6), 626-634. https://www.ncbi.nlm.nih.gov/pmc/articles/PMC3307935/

Khalif, S, N., Alzahrami, M. M. \& Siddiqui, A. F.(2018). Unmet need and demand for family planning among married women of Abha Asear Region in Saudi Arabia. Middle East Fertility Society Journal, volume 23, issue 1, 31 - 36

Machiyama, K. \& Cleland, J. (2013). Unmet need for family planning in Ghana: Trends and determinants.IUSSP Working Paper. https://www.popcouncil.org/uploads/pdfs/2013RH_STEPUP_UnmetNeedGhanaIUSSPw p.pdf

Nmadu, A. G., Joshua, I. A., Omole, V. N., Usman, N. O., Igboanusi, C. J., \& Gobir, A. A. (2019). Male involvement in family planning in Northern Nigeria: A review of literature. Journal of Medicine in the Tropics, 21, 6-9

Numes-Coll, C., Ewerling, F.,Hellwig,F. \& Bamos, A,(2019). Reproductive Health 2019. https://doi:org/10.1186/s12979-019-0680-9 
Ochako, R., Askew,I. \& Temmerman, M. (2016). Modern contraceptive use among migrant and non-migrant women in Kenya. Reproductive Health. https:www.ncbi.nlm.nih.gov>article

Okanlawon, K., Reeves, M., \& Agbaje, O., F. (2010). Contraceptive use: Knowledge, perceptions and attitudes of refugee youths in Oru Refugee Camp, Nigeria. African Journal of Reproductive Health, December 2010; 14(4): 26

Omondi, C.O. (2019). Women's health and action research centre. African Journal of Reproductive Health, 23(2), https:// www.bioline.org.br/rh

Sedgh, G., Ashford, L. S. \& Hussain, R. (2016). Unmet need for contraception in developing countries: examining women's reasons for not using a method.

Sensoy,N., Karkut,Y., Akturan,S., Yiimaz, M. \& Timcel, C. B. (2017). ResearchGate. doi:10.5772/intechopen.73255

Solanke, B. L. (2017). Factors Influencing Contraceptive Use and Non-Use Among Women of Advance Reproductive Age in Nigeria. Journal of Health Population and Nutrition, https://doi:org/10.1186/s4/043-06-0077-6

United Nations Organisation (2008). Achieving sustainable development and promoting development cooperation: Dialogues at the Economic and Social Council. https: //www.un.org/en/ecosoc/docs/pdfs/fina_08-45773.pdf

United Nations Population Fund (2008). Reducing unmet need for family planning: Evidencebased strategies and approaches. Outlook $25^{\text {th }}$ Anniversary

United Nations High Commission for Refugees (2017. Nigeria situation. https://www.unhcr.org $>$.......

Wang, W., Staveteig, S., Winter,R. \& Allen, C. (2017). Women'e Marital Status, Contraceptive Use, and Unmet Need in Sun-Saharan Africa, Latin America, and Caribbean. DHS Comparative Report 44., ICF, Rockville, Maryland, USA 